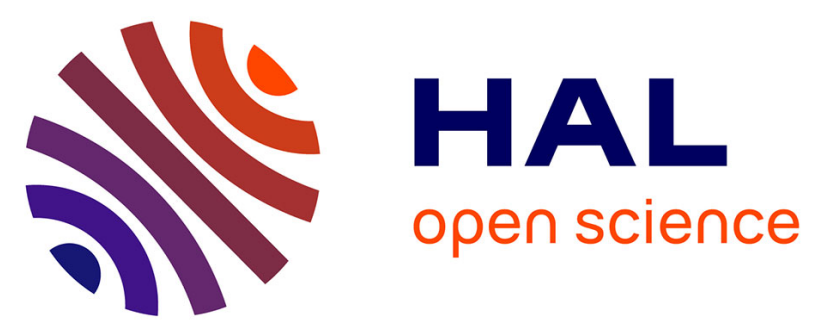

\title{
Selective Formation of an FeIV O or an FeIII OOH Intermediate From Iron(II) and H2 O2: Controlled Heterolytic versus Homolytic Oxygen-Oxygen Bond Cleavage by the Second Coordination Sphere.
}

Khaled Cheaib, M. Qadri E. Mubarak, Katell Sénéchal-David, Christian Herrero, Régis Guillot, Martin Clémancey, Jean-Marc Latour, Sam P. de Visser, Jean-Pierre Mahy, Frédéric Banse, et al.

\section{To cite this version:}

Khaled Cheaib, M. Qadri E. Mubarak, Katell Sénéchal-David, Christian Herrero, Régis Guillot,, et al.. Selective Formation of an FeIV O or an FeIII OOH Intermediate From Iron(II) and H2 O2 : Controlled Heterolytic versus Homolytic Oxygen-Oxygen Bond Cleavage by the Second Coordination Sphere.. Angewandte Chemie International Edition, 2019, 58 (3), pp.854-858. 10.1002/anie.201812724 . hal02121700

\author{
HAL Id: hal-02121700 \\ https://hal.science/hal-02121700
}

Submitted on 22 Nov 2021

HAL is a multi-disciplinary open access archive for the deposit and dissemination of scientific research documents, whether they are published or not. The documents may come from teaching and research institutions in France or abroad, or from public or private research centers.
L'archive ouverte pluridisciplinaire HAL, est destinée au dépôt et à la diffusion de documents scientifiques de niveau recherche, publiés ou non, émanant des établissements d'enseignement et de recherche français ou étrangers, des laboratoires publics ou privés. 


\section{Selective Formation of an FelVO or an FelllOOH Intermediate From Fell-H2O2 : Controlled Heterolytic vs Homolytic O-O Bond Cleavage by the Second Coordination Sphere \\ DOI:}

10.1002/anie.201812724

\section{Document Version}

Accepted author manuscript

Link to publication record in Manchester Research Explorer

\section{Citation for published version (APA):}

Cheaib, K., Mubarak, M. Q. E., Sénéchal-david, K., Herrero, C., Guillot, R., Clémancey, M., Latour, J., De Visser, S., Mahy, J., Banse, F., \& Avenier, F. (2018). Selective Formation of an FelVO or an FelllOOH Intermediate From Fell-H2O2 : Controlled Heterolytic vs Homolytic O-O Bond Cleavage by the Second Coordination Sphere.

Angewandte Chemie International Edition. https://doi.org/10.1002/anie.201812724

\section{Published in:}

Angewandte Chemie International Edition

\section{Citing this paper}

Please note that where the full-text provided on Manchester Research Explorer is the Author Accepted Manuscript or Proof version this may differ from the final Published version. If citing, it is advised that you check and use the publisher's definitive version.

\section{General rights}

Copyright and moral rights for the publications made accessible in the Research Explorer are retained by the authors and/or other copyright owners and it is a condition of accessing publications that users recognise and abide by the legal requirements associated with these rights.

\section{Takedown policy}

If you believe that this document breaches copyright please refer to the University of Manchester's Takedown Procedures [http://man.ac.uk/04Y6Bo] or contact uml.scholarlycommunications@manchester.ac.uk providing relevant details, so we can investigate your claim.

\section{OPEN ACCESS}




\title{
Selective Formation of an $\mathrm{Fe}^{\mathrm{IV} \mathrm{O}}$ or an $\mathrm{Fe}$ "IIOOH Intermediate From $\mathrm{Fe}^{\prime \prime}-\mathrm{H}_{2} \mathrm{O}_{2}$ : Controlled Heterolytic vs Homolytic O-O Bond Cleavage by the Second Coordination Sphere
}

\author{
Khaled Cheaib, ${ }^{a}$ M. Qadri E. Mubarak, ${ }^{b}$ Katell Sénéchal-David, ${ }^{a}$ Christian Herrero, ${ }^{a}$ Régis Guillot, ${ }^{a}$ \\ Martin Clémancey, ${ }^{c}$ Jean-Marc Latour, ${ }^{c}$ Sam P. de Visser, ${ }^{* b}$ Jean-Pierre Mahy, ${ }^{a}$ Frédéric Banse, ${ }^{\text {a }}$ \\ Frédéric Avenier ${ }^{\star a}$
}

\begin{abstract}
Direct formation of $\mathrm{Fe}^{\mathrm{IV}}$-oxo species from nonheme $\mathrm{Fe}^{\mathrm{II}}$ complexes and $\mathrm{H}_{2} \mathrm{O}_{2}$ is highly attractive for the development of selective oxidation reactions. Nonetheless, when using this oxidant, most of the $\mathrm{Fe}^{\prime \prime}$ species known to date undergo a single electron oxidation generating $\mathrm{Fe}^{\mathrm{III}}$ and hydroxyl radicals prone to engaging in uncontrolled radical chemistry. Here, we demonstrate that the devised incorporation of a dialkylamine group into the second coordination sphere of an $\mathrm{Fe}^{\text {ll }}$ complex allows to switch the reactivity from the usual formation of $\mathrm{Fe}^{\text {IIII }}$ species towards the selective generation of an $\mathrm{Fe}^{\mathrm{IV}}$-oxo intermediate. We characterized the $\mathrm{Fe}^{\mathrm{IV}}$ oxo complex by UV-visible absorption and Mössbauer spectroscopy. Variable temperature kinetic analyses point towards a mechanism where the heterolytic cleavage of the $\mathrm{O}-\mathrm{O}$ bond is triggered by a proton transfer from the proximal to the distal oxygen atom in the $\mathrm{Fe}^{\mathrm{II}}-\mathrm{H}_{2} \mathrm{O}_{2}$ complex with the assistance of the pendant amine. Density functional theory studies reveal that this heterolytic cleavage is actually initiated by an homolytic $\mathrm{O}-\mathrm{O}$ bond cleavage immediately followed by a proton-coupled electron transfer that leads to the formation of the $\mathrm{Fe}^{\mathrm{IV}}$-oxo species and release of water through a concerted mechanism.
\end{abstract}

More than a century ago, Fenton discovered that the reaction of an $\mathrm{Fe}$ " species with $\mathrm{H}_{2} \mathrm{O}_{2}$ led to the efficient oxidation of organic substrates in acidic aqueous media. ${ }^{[1]}$ Ever since that discovery, debate continues on whether the active species of such systems is an $\mathrm{OH}$ radical ${ }^{[2-4]}$ or an $\mathrm{Fe}^{\mathrm{IV}}$-oxo species ${ }^{[5]}$ resulting from either the homolytic or heterolytic cleavage of the $\mathrm{O}-\mathrm{O}$ bond in its $\mathrm{Fe}$ peroxide precursor. Beyond this historical controversy, understanding the key steps in the reactivity of $\mathrm{Fe}^{\prime \prime}$ species with $\mathrm{H}_{2} \mathrm{O}_{2}$ is of great interest for the development of synthetic

[a] Dr. K. Cheaib, Dr. C. Herrero, Dr. K. Sénéchal-David, Dr. Guillot, Pr. J.-P. Mahy, Pr. F. Banse, Dr. F. Avenier Institut de Chimie Moléculaire et des matériaux d'Orsay (UMR 8182) Univ Paris Sud, Université Paris Saclay. 91405 Orsay cedex, France

E-mail: frederic.banse@u-psud.fr, frederic.avenier@u-psud.fr

[b] Mr M. Q. E. Mubarak, Dr S. P. de Visser

Manchester Institute of Biotechnology and School of Chemical Engineering and Analytical Science

The University of Manchester

131 Princess Street, Manchester M1 7DN, United Kingdom

E-mail: sam.devisser@manchester.ac.uk

[c] Dr M. Clémancey, Dr J.-M. Latour

LCBM/PMB and CEA/BIG/CBM/ and CNRS UMR 5249, Université Grenoble Alpes, Grenoble 38054, France

Supporting information for this article is given via a link at the end of the document. oxidation catalysts. Indeed, the production of high-valent Fe-oxo species capable of performing a priori selective 2-electron oxidation reactions, instead of hydroxyl radicals that would engage in uncontrolled oxidations has been a long term goal. ${ }^{[6]}$ Recent works suggest that changing the experimental conditions such as the $\mathrm{pH}$ may drive the reaction to a pathway or another. ${ }^{[7,8]}$ Additionally, understanding the reaction between $\mathrm{Fe}^{\text {II }}$ and $\mathrm{H}_{2} \mathrm{O}_{2}$ is relevant to the comprehension of $\mathrm{O}_{2}$ activation at the $\mathrm{Fe}^{\text {II }}$ centers of $\mathrm{Fe}$ enzymes ${ }^{[9]}$ such as tetrahydropterindependent monooxygenases, ${ }^{[10]}$ or isopenicilin $N$ synthase ${ }^{[11]}$ It has been suggested that during the $\mathrm{O}_{2}$ activation process by these enzymes, an $\mathrm{Fe}^{\mathrm{lV}}$-oxo species is formed via the heterolytic $\mathrm{O}-\mathrm{O}$ cleavage of an $\mathrm{Fe}$ "OOR $(\mathrm{H})$ intermediate. However, this reaction proved to be difficult to reproduce with synthetic catalysts and most of the $\mathrm{Fe}^{\mathrm{IV}}$-oxo species known to date have been obtained from the reaction of $\mathrm{Fe}^{\prime \prime}$ complexes with oxygen donors such as iodosylbenzene (PhlO) or $m$-chloroperbenzoic acid (mCPBA). ${ }^{[12,13]}$ The use of $\mathrm{H}_{2} \mathrm{O}_{2}$ with $\mathrm{Fe}$ "l complexes usually leads to the formation of the corresponding $\mathrm{Fe}^{\text {III }}$ complexes under stoichiometric conditions and yields $\mathrm{Fe}^{\text {III } \mathrm{OOH}}$ intermediates with excess $\mathrm{H}_{2} \mathrm{O}_{2} \cdot{ }^{[14-17]}$ Only a few examples of nonheme $\mathrm{Fe}^{\text {ll }}$ complexes have shown the direct formation of an $\mathrm{Fe}^{\mathrm{IV}}$-oxo species from their reaction with $\mathrm{H}_{2} \mathrm{O}_{2},{ }^{[18,19]}$ or from the evolution of a putative $\mathrm{Fe} \mathrm{OOOH}(\mathrm{R})$ intermediate. ${ }^{[20]}$ Que et al. reported the nearly quantitative formation of $\left[\mathrm{Fe}^{\mathrm{IV}} \mathrm{O}(\mathrm{TMC})\right]^{2+}$ from $\left[\mathrm{Fe}^{\prime \prime}(\mathrm{TMC})\right]^{2+}$ and $\mathrm{H}_{2} \mathrm{O}_{2}$ in the presence of 2,6-lutidine. ${ }^{[18]}$ DFT calculations showed that lutidine acted as a general base that promoted the proton transfer from the proximal to the distal $O$ atom, thus facilitating the heterolytic $\mathrm{O}-\mathrm{O}$ cleavage. ${ }^{[21]}$ The role played by lutidine was similar to that played by the distal His residue in horseradish peroxidase (HRP), ${ }^{[22]}$ with the exception that it was added as a cofactor in solution and was not part of the catalyst scaffold. Thus, we reasoned that designing a ligand containing a non-coordinating base in the vicinity of the $\mathrm{Fe}^{\|}$ion would drastically influence its reactivity versus $\mathrm{H}_{2} \mathrm{O}_{2}$. Herein, we demonstrate that the incorporation of a secondary amine as a second coordination sphere group in the $\left[\mathrm{Fe} "(\mathrm{Bn} \text {-tpen) }]^{2+}\right.$ complex $2^{\text {II }}$ to give the new [Fe" $\left({ }^{\mathrm{NH}} \mathrm{Bn} \text {-tpen) }\right]^{2+} 1^{11}$ (Fig. 1) allows the direct formation of the $\left[\mathrm{Fe}^{\mathrm{IV}} \mathrm{O}\left({ }^{\mathrm{NH}} \mathrm{Bn} \text {-tpen }\right)\right]^{2+}$ species $1^{\mathrm{IV}}-\mathbf{O}$ from the stoichiometric reaction between $1^{\text {II }}$ and $\mathrm{H}_{2} \mathrm{O}_{2}$. Interestingly, the reactivity of $1^{11}$ turns into the conventional reactivity of the original complex $2^{\text {II }}$ when the amine group is protonated, i.e. formation of an $\mathrm{Fe}^{\text {IIII }}$ species. ${ }^{[23]}$ Experimental and theoretical investigations of $\mathbf{1}^{\mathrm{IV}}-\mathbf{O}$ formation converge towards a heterolytic $\mathrm{O}-\mathrm{O}$ cleavage of the initial $\mathrm{Fe}^{\mathrm{II}}-\mathrm{H}_{2} \mathrm{O}_{2}$ complex promoted by a proton transfer assisted by the neighbouring amine. To the best of our knowledge, this is the 
first example of a nonheme $\mathrm{Fe}$ system where such a transformation is performed via an intra-molecular reaction.

The ${ }^{\mathrm{NH}} \mathrm{Bn}$-tpen ligand was designed in such a way that the secondary amine fragment could not bind the metal through a stable 5- or 6-membered metallocycle. The X-ray structure of $\left[\mathrm{Fe}{ }^{\mathrm{Il}}\left({ }^{\mathrm{NH}} \mathrm{Bn} \text {-tpen }\right)\left(\mathrm{OH}_{2}\right)\right]^{2+}\left(\mathbf{1}^{\mathrm{II}}\right)$ is displayed in Fig. 1. It shows that the first coordination sphere of $\mathrm{Fe}^{\prime \prime}$ is constituted of the typical $\mathrm{N}_{5}$ environment provided by $\mathrm{Bn}$-tpen and related ligands ${ }^{[23-25]}$ and confirms that the secondary amine (N6) is not coordinated to the metal center. The coordination sphere is completed by a water ligand, which is $\mathrm{H}$-bonded to the secondary amine $\mathrm{N}$-atom of the neighboring complex in the crystal (S.I., Fig. S1). The mean Fe$\mathrm{N}$ bond distance is $2.21 \AA$, which is typical of a high spin $(\mathrm{S}=2)$ $\mathrm{Fe}^{\mathrm{II}}$. Further characterizations indicate that the structure of $1^{\text {II }}$ is preserve in solution (S.I. Fig. S2 and S3).
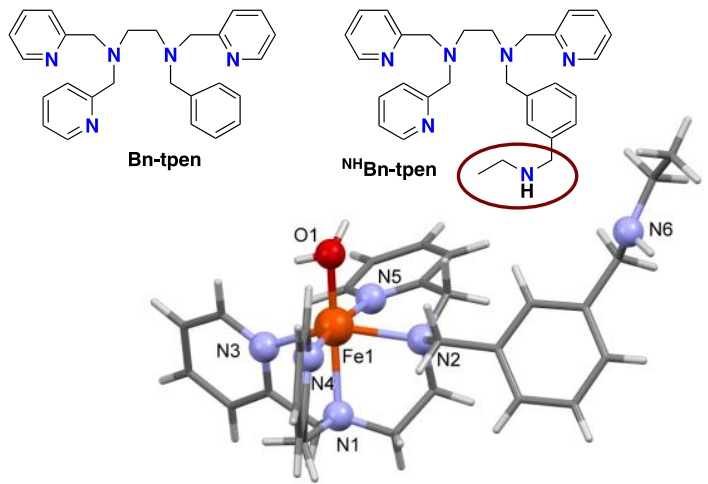

Figure 1. Structure of the ${ }^{\mathrm{NH}} \mathrm{Bn}$-tpen and $\mathrm{Bn}$-tpen ligands and $\mathrm{X}$-ray structure of the molecular cation, 1". Anions and disordered atoms were omitted for clarity. Bond distances (Å): Fe-N1 2.24, Fe-N2 2.24, Fe-N3 2.15, Fe-N4 2.18,, Fe-N5 2.23, Fe-O1 1.92.

The reaction of $1^{\prime \prime}$ ( $1 \mathrm{mM}$ ) with 2.5 equiv. $\mathrm{H}_{2} \mathrm{O}_{2}$ in $\mathrm{MeOH}$ at $25^{\circ} \mathrm{C}$ monitored by stopped flow absorbance spectroscopy leads to the formation of a new species with an absorbance of 0.18 at $740 \mathrm{~nm}$ and a shoulder at $900 \mathrm{~nm}$ (Fig. 2, green trace). Under these conditions, the maximum accumulation of this species occurred after $3 \mathrm{~s}$ but decayed afterwards (S.I., Fig. S4). Addition of PhIO (25 equiv. vs Fe) as oxidant instead of $\mathrm{H}_{2} \mathrm{O}_{2}$ yielded the same intermediate (S.I., Fig. S5). Its spectroscopic signature is very similar to that observed for the $\left[\mathrm{Fe}^{\mathrm{IV}} \mathrm{O}(\mathrm{Bn}\right.$ tpen) $]^{2+}$ species, $2^{\mathrm{IV}}-\mathrm{O}\left(\lambda_{\max }=739 \mathrm{~nm}\right.$ with a shoulder at $900 \mathrm{~nm}$, $\varepsilon=400 \mathrm{M}^{-1} \mathrm{~cm}^{-1}$ in acetonitrile). ${ }^{[6]}$ Hence, the intermediate observed in Fig. 2 can be assigned as $\left[\mathrm{Fe}^{\mathrm{IV}} \mathrm{O}\left({ }^{\mathrm{NH}} \mathrm{Bn} \text {-tpen) }\right]^{2+} \mathbf{1}^{\mathrm{IV}}-\mathrm{O}\right.$ The observation of an isosbestic point at $495 \mathrm{~nm}$ and the absence of any other intermediate in the course of the formation of $1^{\mathrm{IV}}-\mathrm{O}$ suggests its direct formation from $1^{\mathrm{II}}$ and $\mathrm{H}_{2} \mathrm{O}_{2}$.

To further substantiate this assignment, the reaction product of $1^{\prime \prime}$ with $\mathrm{H}_{2} \mathrm{O}_{2}$ was studied by Mössbauer spectroscopy. Fig. 2 shows the spectra obtained when a $\mathrm{CD}_{3} \mathrm{OD}$ solution of ${ }^{57} \mathrm{Fe}-$ enriched $1^{\text {Il }}$ was reacted with 10 equiv. $\mathrm{D}_{2} \mathrm{O}_{2}$ for ca. $5 \mathrm{~s}$ and frozen. The spectra of the solution recorded at either $80 \mathrm{~K}$ (not shown) or $4.5 \mathrm{~K}$ (Fig. 2A) in absence of magnetic field was dominated by a quadrupole doublet which can be simulated with a set of parameters $\delta=0.015 \mathrm{~mm} / \mathrm{s}$ and $\Delta \mathrm{E}_{\mathrm{Q}}=0.83 \mathrm{~mm} / \mathrm{s}$. These values are very close to those reported for $2^{\mathrm{IV}}-\mathbf{O}(\delta=0.01$ $\mathrm{mm} / \mathrm{s}$ and $\left.\Delta \mathrm{E}_{\mathrm{Q}}=0.87 \mathrm{~mm} / \mathrm{s}\right)^{[26]}$ and in the usual range for $\mathrm{Fe}^{\mathrm{IV} \mathrm{O}}$ species with $S=1 .^{[12]}$ This value of the spin was verified by performing an experiment under a field of $6 \mathrm{~T}$ applied parallel to the $y$ ray. The corresponding spectrum (Fig. 2B) could be nicely simulated under this assumption with an axial zero field splitting value of $21 \mathrm{~cm}^{-1}$. The quadrupole doublet accounts for ca $90 \%$ of total $\mathrm{Fe}$ in the sample and the remaining $\mathrm{Fe}$ is probably present as ferric impurities as judged from the extra lines spread on both sides of the doublet in Fig. $2 \mathrm{~A}$. Note that a sample obtained with 2.5 equiv. $\mathrm{D}_{2} \mathrm{O}_{2}$ vs $\mathbf{1}^{\prime \prime}$ displayed identical spectroscopic characteristics.
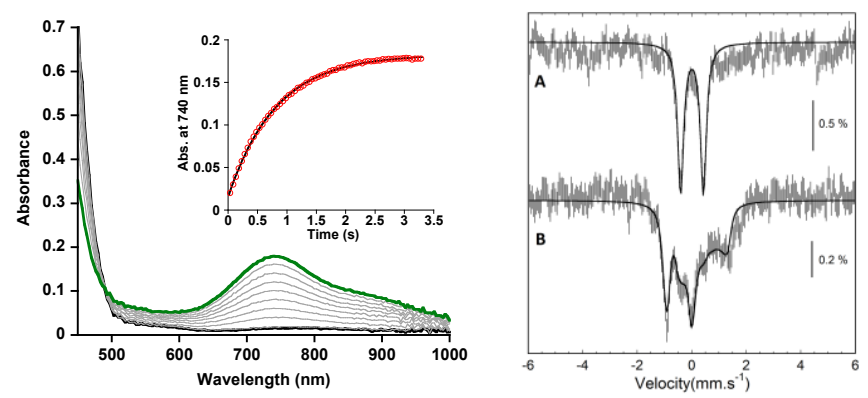

Figure 2. (Left) Time resolved UV-Vis spectra for the reaction of $1^{\prime \prime}(1 \mathrm{mM})$ with 2.5 equiv. $\mathrm{H}_{2} \mathrm{O}_{2}$ in $\mathrm{MeOH}$ at $25^{\circ} \mathrm{C}$. Black trace, spectrum recorded $12 \mathrm{~ms}$ after mixing the reactants. Green trace, spectrum recorded at the maximum of the formation of $1^{\mathrm{IV}}-\mathrm{O}(\mathrm{t}=3 \mathrm{~s})$. Insert: time trace monitored at $740 \mathrm{~nm}$ (red circles) and first order fitting of the curve (black trace). (Right) Mössbauer spectra of $1^{\text {IV }}$-O (vertical bars) recorded at $4.5 \mathrm{~K}$ in absence $(A)$ and presence $(B)$ of a magnetic field of $6 \mathrm{~T}$ applied parallel to the $\mathrm{Y}$ ray. The black line is a spinHamiltonian simulation of both spectra with a unique set of parameters: $\delta=$ $0.015 \mathrm{~mm} / \mathrm{s}, \Delta \mathrm{E}_{\mathrm{Q}}=0.83 \mathrm{~mm} / \mathrm{s}, \mathrm{D}=21 \mathrm{~cm}^{-1}, \mathrm{E} / \mathrm{D}=0, \mathrm{~g}_{\mathrm{x}}=\mathrm{g}_{\mathrm{y}}=2.3$, and $\mathrm{g}_{\mathrm{z}}=$ 2.0, $A_{x, y, z} / g_{N} \beta N=(-18,-18,-2) \mathrm{T}, \eta=0.26$.

Titration of $1^{\text {II }}$ with $\mathrm{H}_{2} \mathrm{O}_{2}$ shows that the amount of $1^{\mathrm{IV}}-\mathrm{O}$ formed was constant and maximum from 5 equiv. of added $\mathrm{H}_{2} \mathrm{O}_{2}$ up to 100 equiv. (S.I., Fig. S6). Considering that the reaction is quantitative under these conditions, an extinction coefficient of $190 \mathrm{M}^{-1} . \mathrm{cm}^{-1}$ for the $740 \mathrm{~nm}$ chromophore is deduced. ${ }^{[27]}$ Additionally, the conversion in $1^{\mathrm{IV}}-\mathrm{O}$ reached $80 \%$ and $93 \%$, respectively, when 1 and 2.5 equiv. $\mathrm{H}_{2} \mathrm{O}_{2}$ were used. These results thus strongly suggest a 1:1 stoichiometry between $\mathbf{1}^{\text {II }}$ and $\mathrm{H}_{2} \mathrm{O}_{2}$ to yield $1^{\mathrm{IV}}-\mathrm{O}$. Consistently, further kinetic studies using different concentrations of $\mathrm{H}_{2} \mathrm{O}_{2}$ revealed that the reaction is first-order in both $1^{11}$ and $\mathrm{H}_{2} \mathrm{O}_{2}$. At $25^{\circ} \mathrm{C}$, a second-order rate constant of $0.316 \mathrm{~L} . \mathrm{mmol}^{-1} . \mathrm{s}^{-1}$ was obtained from the plot of the pseudo first-order rate constant $k_{o b s} v s\left[\mathrm{H}_{2} \mathrm{O}_{2}\right]$ (S.I., Fig. S7). The temperature dependence of $k_{\text {obs }}$ was evaluated for samples containing $1 \mathrm{mM} \mathrm{1"}$ and 10 equiv. $\mathrm{H}_{2} \mathrm{O}_{2}$. The resulting Eyring plot afforded an activation enthalpy $\Delta \mathrm{H}^{\ddagger}$ of $3.75 \mathrm{kcal}^{\mathrm{mol}}{ }^{-1}$ and an activation entropy $\Delta S^{\ddagger}$ of $-43.3 \mathrm{cal} . \mathrm{mol}^{-1}$. $\mathrm{K}^{-1}$ (S.I., Fig. S8). These activation parameters compare well with those obtained for the formation of $\mathrm{Fe}^{\mathrm{IV}}$-oxo intermediates upon reaction of $\mathrm{H}_{2} \mathrm{O}_{2}$ with Fe"(bispidine) $\left(\Delta \mathrm{H}^{\ddagger}=8.1 \mathrm{kcal} \cdot \mathrm{mol}^{-1}, \Delta \mathrm{S}^{\ddagger}=-35.9 \mathrm{cal} \cdot \mathrm{mol}^{-1} \cdot \mathrm{K}^{-1}\right)^{[19]}$ or Fe $(T M C)$ in the presence of 2,6-lutidine $\left(\Delta \mathrm{H}^{\ddagger}=6.9 \mathrm{kcal}^{\prime \prime} \mathrm{mol}^{-1}\right.$, $\left.\Delta S^{\ddagger}=-34.4 \mathrm{cal} \cdot \mathrm{mol}^{-1} \cdot \mathrm{K}^{-1}\right)^{[18]}$. For the latter complex, the formation of the $\mathrm{Fe}^{\mathrm{IV}}$-oxo was explained as a global heterolytic O-O bond cleavage assisted by the external base which resulted from a combination of partial homolytic $\mathrm{O}-\mathrm{O}$ cleavage and protoncoupled electron transfer as determined by DFT calculations. ${ }^{[21]}$ 
The smaller activation enthalpy observed here suggests that, compared to an external base, the preorganization of the amine next to the metal center facilitates the formation of the $\mathrm{Fe}^{\mathrm{IV}}$-oxo intermediate.

To support the crucial role played by the dialkylamine group in the formation of $\mathbf{1}^{\mathrm{IV}}-\mathbf{O}$, similar experiments were performed under acidic conditions in the presence of 2 equiv. $\mathrm{HClO}_{4}$ vs $1^{\prime \prime}$. Under these conditions and even for a small amount of added $\mathrm{H}_{2} \mathrm{O}_{2}$ (2.5 equiv. vs $\mathrm{Fe}$ ), formation of a low spin $(\mathrm{S}=1 / 2) \mathrm{Fe}$ "ll $\mathrm{OOH}$ intermediate was observed with typical UV-visible $\left(\lambda_{\max }=539\right.$ $\mathrm{nm})$ and EPR $(g=2.21,2.14,1.97)$ features ${ }^{[23,28,29]}$ (Fig. 3 and Scheme 1). In the presence of protons, the reactivity of $1^{11}$ switches to the conventional Fe $\mathrm{Fe}^{\text {II }}$-to-Fe ${ }^{\text {IIII }}$ reactivity exhibited by most of nonheme Fe" complexes supported by pentadentate ligands. ${ }^{[14,17,23,28-32]}$ Conversely, in its neutral form, the amine interacts specifically with the $\mathrm{Fe}^{\prime \prime}-\mathrm{H}_{2} \mathrm{O}_{2}$ adduct to promote the heterolytic $\mathrm{O}-\mathrm{O}$ bond cleavage to yield $1^{\mathrm{IV}}-\mathrm{O}$, with the function of a springboard that relays protons between the proximal and distal oxygen atoms of $\mathrm{H}_{2} \mathrm{O}_{2}$. To substantiate our hypothesis, additional experiments were carried out using $\mathrm{D}_{2} \mathrm{O}_{2}$ in $\mathrm{CD}_{3} \mathrm{OD}$. Under these conditions, the formation of $1^{\mathrm{IV}}-\mathrm{O}$ was observed as well, and a large kinetic isotope effect $\left(\mathrm{KIE}, \mathrm{k}_{\mathrm{H}} / \mathrm{K}_{\mathrm{D}}\right)$ of 5.6 was measured (S.I., Fig. S9). A similar value was reported by Li et al. for the formation of $\left[\mathrm{Fe}^{\mathrm{IV}} \mathrm{O}(\mathrm{TMC})\right]^{2+}$ from the $\mathrm{Fe}^{\mathrm{Il}}$ complex and 2,6-lutidine as a base. ${ }^{[18]}$

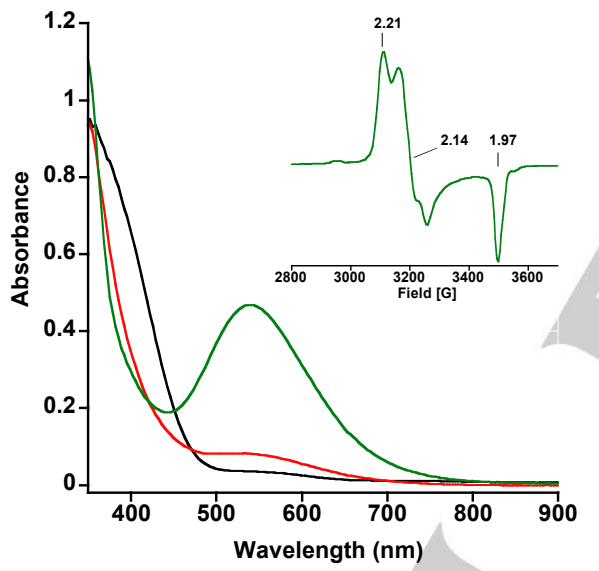

Figure 3. UV-Vis. spectra of $1^{\mathrm{II}}$ in $\mathrm{MeOH}$ in the presence of $\mathrm{HClO}_{4}$ (2 equiv.) before (black trace) and after addition of $\mathrm{H}_{2} \mathrm{O}_{2}$ (2.5 equiv., red trace or 100 equiv., green trace). Insert: X-band EPR spectrum at $100 \mathrm{~K}$ of the sample corresponding to the green UV-Vis. spectrum (Power $0.12 \mathrm{~mW}$ ).

Given all the above observations, i.e., (i) a direct conversion between $\mathbf{1}^{\mathrm{II}}$ and $\mathbf{1}^{\mathrm{IV}}-\mathbf{O}$, (ii) first-order kinetics in both $\mathrm{Fe}$ "l and $\mathrm{H}_{2} \mathrm{O}_{2}$, (iii) activation parameters consistent with $\mathrm{O}-\mathrm{O}$ bond heterolysis and (iv) the implication of both protons and the amine in the second coordination sphere, one can suggest that the formation of $1^{1 \mathrm{v}}-\mathrm{O}$ is initiated by the heterolytic cleavage of an $\mathrm{Fe}-\mathrm{H}_{2} \mathrm{O}_{2}$ intermediate promoted by the dialkylamine group acting as an acid-base relay. The role of this latter moiety being similar to the one assigned to distal histidine or glutamate residues in heme peroxidases. ${ }^{[2,33,34]}$

To gain more insight into the mechanism of the binding and activation of $\mathrm{H}_{2} \mathrm{O}_{2}$ on $1^{\prime \prime}$, a series of DFT calculations were performed. We started from the ${ }^{1,3,5}\left[\mathrm{Fe}^{\mathrm{II}}\left(\mathrm{H}_{2} \mathrm{O}_{2}\right)\left({ }^{\mathrm{NH}} \mathrm{Bn} \text {-tpen }\right)\right]^{2+}$

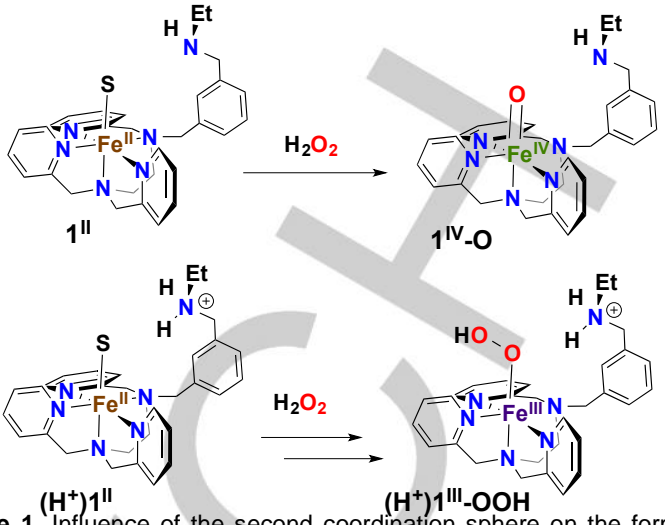

Scheme 1. Influence of the second coordination sphere on the formation of $\mathrm{Fe}^{\mathrm{IV}} \mathrm{O}$ and $\mathrm{Fe}$ "II $\mathrm{OOH}$ intermediates as observed in this work. (with $\mathrm{S}=\mathrm{H}_{2} \mathrm{O}$ or $\mathrm{MeOH})$

$\left({ }^{1,3,5} 1^{\prime \prime}-\mathrm{H}_{2} \mathrm{O}_{2}\right)$ complexes in either the singlet, triplet or quintet spin state. First, ${ }^{\mathrm{II}}-\mathrm{H}_{2} \mathrm{O}_{2}$ was optimized in various orientations of $\mathrm{H}_{2} \mathrm{O}_{2}$ with respect to the metal center and dialkylamine group. In particular, orientation (a) has the distal $\mathrm{OH}$ group of $\mathrm{H}_{2} \mathrm{O}_{2}$ in hydrogen bonding interaction with the pendant amine group (1"$\mathrm{H}_{2} \mathrm{O}_{2}-\mathbf{a}$ ), whereas in the alternative structure the proximal $\mathrm{OH}$ group was hydrogen bonded to the amine $\left(\mathbf{1}^{\prime \prime}-\mathrm{H}_{2} \mathrm{O}_{2}\right.$-b) (Fig. 4 and S.I., Fig. S10). Test calculations with a range of density functional methods were performed including the full reaction mechanism with B3LYP and PBE1PBE DFT methods. Both density functional methods give virtually the same reaction mechanism and the only difference relates to the relative energies of the various complexes. Our results are consistent with a recent benchmark study that showed these methods to reproduce experimental free energies of activation for the reaction of nonheme $\mathrm{Fe}^{\mathrm{IV}}$-oxo with substrates to within $3 \mathrm{kcal}$ $\mathrm{mol}^{-1}{ }^{[35,36]}$ Finally, as the spin-state ordering of the $\mathrm{Fe}^{\mathrm{IV}}$-oxo species is sometimes sensitive to the choice of the density functional method, we calculated the $\mathrm{Fe}^{\mathrm{IV}}$-oxo species with several methods and procedures (S.I. Table S9). With all methods, apart from BP86, the triplet spin $1^{\mathrm{IV}}-\mathrm{O}$ is the ground state in agreement with the Mössbauer studies reported above. Despite these fluctuations in spin-state energies, previous studies of ours; however, showed that changing the density functional method generally does not change regio- and stereoselectivities of a chemical reaction but only affects the relative energies. $^{[37,38]}$

In the triplet and quintet spin states, the $\mathbf{1}^{\prime \prime}-\mathrm{H}_{2} \mathrm{O}_{2}$-a and $\mathbf{1}^{\prime \prime}-\mathrm{H}_{2} \mathrm{O}_{2-}$ b structures are close in energy with a small preference of the latter at B3LYP level of theory. Well higher in energy than these quintet spin $\mathrm{H}_{2} \mathrm{O}_{2}$ complexes are the triplet spin states., Therefore, the triplet spin ${ }^{3} 1^{11}-\mathrm{H}_{2} \mathrm{O}_{2}$ will not play a role in the reaction mechanism leading to the formation of the $\mathrm{Fe}^{\mathrm{IV}}$-oxo species. Subsequently, we investigated the proton transfer from $\mathrm{H}_{2} \mathrm{O}_{2}$ to the dialkylamine group to form an $\mathrm{Fe}$ "-hydroperoxo intermediate, which is negligible from complex $\mathbf{1}^{11}-\mathrm{H}_{2} \mathrm{O}_{2}$-b (Fig. 4) at B3LYP and PBE1PBE level of theories. 

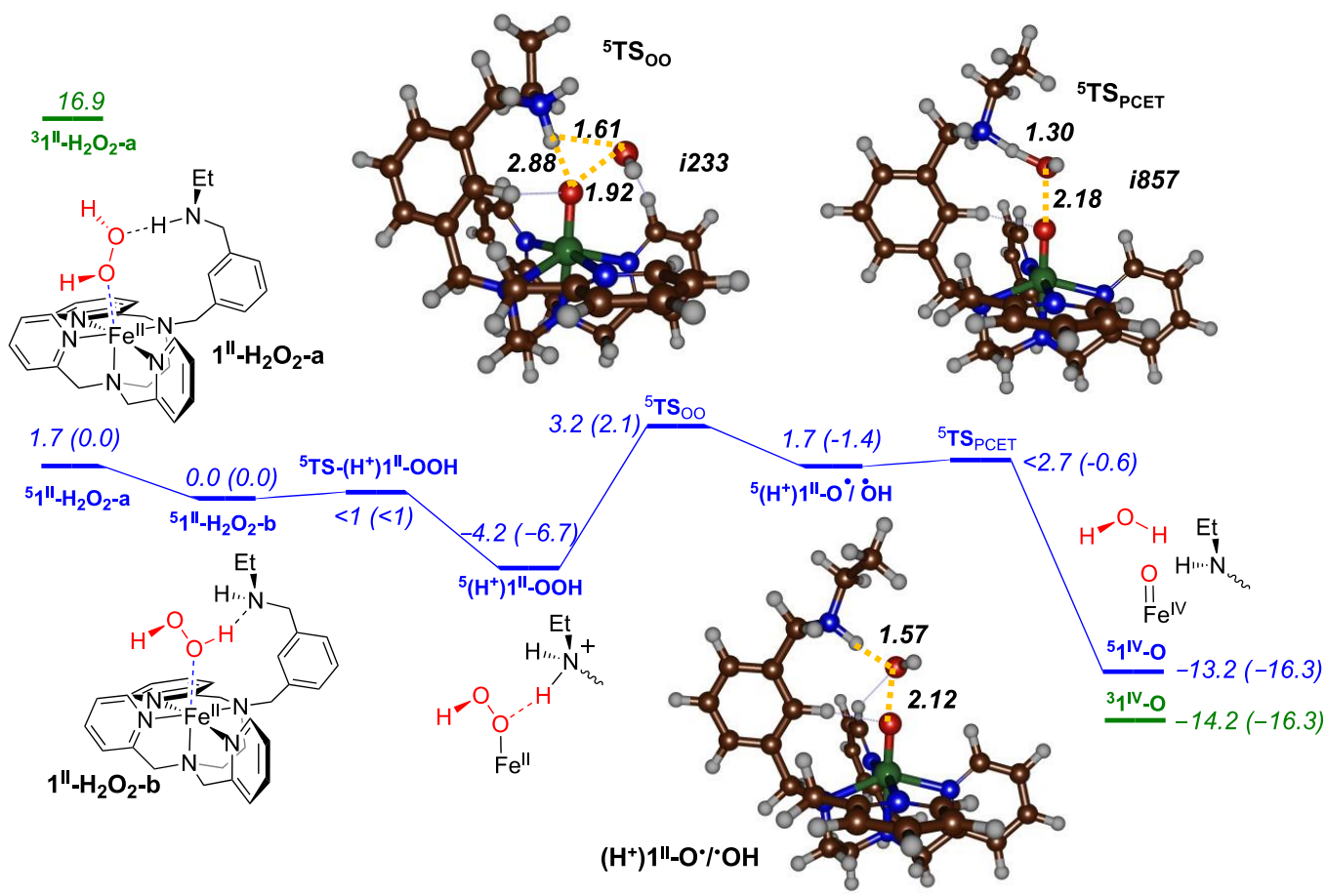

Figure 4. Potential energy landscape for the formation of the $\mathrm{Fe} \mathrm{IV}^{\mathrm{IV}} \mathrm{O}$ species $1^{\mathrm{IV}}-\mathrm{O}$ from the $\mathrm{Fe} \mathrm{e}^{\mathrm{II}}-\mathrm{H}_{2} \mathrm{O}_{2}$ adduct $\mathbf{1}^{\mathrm{II}}-\mathrm{H}_{2} \mathrm{O}_{2}$ as calculated at UB3LYP/BS2//UB3LYP/BS1 level of theory. Energies are in $\mathrm{kcal} \cdot \mathrm{mol}^{-1}$ with $\Delta \mathrm{E}_{\mathrm{BS} 2}+\mathrm{ZPE}$ data outside parenthesis and $\Delta \mathrm{G}_{\mathrm{BS} 2}$ data in parenthesis

However, in the case of $\mathbf{1}^{\prime \prime}-\mathrm{H}_{2} \mathrm{O}_{2}$-a no direct proton transfer from the terminal $\mathrm{OH}$ group could be located. Instead, an internal rotation occurs during the geometry scan and changes structure $1^{\prime \prime}-\mathrm{H}_{2} \mathrm{O}_{2}$-a into $1^{\prime \prime}-\mathrm{H}_{2} \mathrm{O}_{2}$-b.

The geometry scan converges to a proton transfer intermediate $\left(\mathrm{H}^{+}\right) 1^{11}-\mathrm{OOH}$ that shows a hydrogen bond between the nascent ammonium group and the proximal oxygen atom. The next step leads to the cleavage of the hydroperoxo bond in $\left(\mathrm{H}^{+}\right) 1^{\prime \prime}-\mathrm{OOH}$. Similarly to previous calculations on nonheme Fe complexes, ${ }^{[39]}$ we find a homolytic bond breaking to give a formal Fe"-oxyl complex and an $\mathrm{OH}$ radical (S.I., Table S4). In particular, we find an electronic configuration with a spin density of 4.2 on the Fe-oxo unit and a down-spin electron (spin density of -0.6) on the leaving ${ }^{\circ} \mathrm{OH}$ in support of our characterization of $\left(\mathrm{H}^{+}\right) 1^{\prime \prime}$ $\mathbf{0} \% \mathrm{OH}$. The calculated reaction barrier for the homolytic cleavage of the $\mathrm{O}-\mathrm{O}$ bond is $\Delta \mathrm{G}^{\ddagger}=8.8$ (B3LYP) and 15.3 (PBE1PBE) kcal.mol ${ }^{-1}$ via ${ }^{5} \mathrm{TS}$ oo. The latter free energy of activation is in perfect agreement with the experimental Eyring values at $298 \mathrm{~K}_{\text {of }} 16.7 \mathrm{kcal}^{\mathrm{mol}}{ }^{-1}$ (Fig. 4). Attempts to swap molecular orbitals to find an $\mathrm{Fe}^{\mathrm{IV}}$-oxo and an $\mathrm{OH}^{-}$anion converged back to a radical situation in all cases and hence corresponds to a higher energy pathway.

In the final reaction step the $\mathrm{Fe}^{\mathrm{IV}}$-oxo or $\mathbf{1}^{\mathrm{IV}}-\mathrm{O}$ is formed through a simultaneous electron and proton transfer process: namely proton transfer from the pendant ammonium group to the $\mathrm{OH}$ radical and electron transfer from the $\mathrm{Fe}^{\prime \prime}$-oxyl to ${ }^{\circ} \mathrm{OH}$. This pathway has a small barrier of less than $1 \mathrm{kcal} \mathrm{mol}^{-1}$ above $\left(\mathrm{H}^{+}\right) \mathbf{1 1}-\mathbf{0} \% \mathrm{OH}$. Interestingly, the energy surface from $\mathbf{T S}_{\text {oo }}$ to TS $0 \% \mathrm{OH}$ is high in energy), which indicates that these steps will be seen as synchronous and the electron/proton transfer may be seen as coincidental with the initial homolytic $\mathrm{O}-\mathrm{O}$ bond scission. The structures of ${ }^{5} \mathrm{TS}$ Oo, $\left(\mathrm{H}^{+}\right) 1^{11}-\mathrm{O} \% \mathrm{OH}$ and ${ }^{5} \mathrm{TS}$ PCET are displayed in Fig. 4 alongside the reaction profile. Clearly seen, particularly in ${ }^{5} \mathbf{T} \mathbf{S}_{\mathrm{O}}$, are $\mathrm{H}$-bond interactions of the ammonium group with the distal $(1.61 \AA)$ and proximal $(2.88 \AA)$ oxygen atoms. As such, O-O bond cleavage will be affected by $\mathrm{H} / \mathrm{D}$ replacement and should lead to a KIE as observed experimentally. In conclusion, the computational modeling reveals that the activation of $\mathrm{H}_{2} \mathrm{O}_{2}$ indeed occurs via an overall heterolytic cleavage of the initial $\mathrm{Fe}^{\mathrm{I}}-\mathrm{H}_{2} \mathrm{O}_{2}$, as inferred from the experimental data (S.I., Fig. S11). However, the heterolytic cleavage is initiated by a homolytic $\mathrm{O}-\mathrm{O}$ bond cleavage immediately followed by a proton/electron-transfer from the ammonium/Fe" releases water.

Finally, we tested the same reaction mechanism under low $\mathrm{pH}$ conditions, i.e. starting from the $\mathrm{H}_{2} \mathrm{O}_{2}$ bound complex with protonated dialkylamine chain, $\left(\mathrm{H}^{+}\right)-\mathbf{1}^{11}-\mathrm{H}_{2} \mathrm{O}_{2}-\mathbf{b}$. Thus, these calculations start from ${ }^{5,3}\left(\mathrm{H}^{+}\right)-1^{11}-\mathrm{H}_{2} \mathrm{O}_{2}-\mathrm{b}$ and a homolytic O-O bond cleavage barrier of $\Delta \mathrm{G}^{\ddagger}=8.2 \mathrm{kcal} \mathrm{mol}^{-1}$ splits $\mathrm{H}_{2} \mathrm{O}_{2}$ into two $\mathrm{OH}$ radicals directly in an exergonic step of $3.6 \mathrm{kcal} \mathrm{mol}^{-1}$ to form ${ }^{5}\left(\mathrm{H}^{+}\right) \mathbf{1}^{11 '}(\mathrm{OH}) /{ }^{\circ} \mathrm{OH}$ (S.I., Fig. S12). The electronic configuration of the latter consists of an $\mathrm{Fe}^{\text {III }}$-hydroxo with five unpaired electrons on the metal antiferromagnetically coupled to an $\mathrm{OH}$ radical (S.I., Table S15). Subsequently, a proton-coupled electron-transfer barrier gives the $\mathrm{Fe}^{\mathrm{IV}}$-oxo species and a water molecule in a highly exergonic reaction step. These results are in line with the experimental work reported above. In the presence of acid, the substantial barrier for the PCET indicates that the nascent free 
$\cdot \mathrm{OH}$ may be easily scavenged by the $\mathrm{MeOH}$ solvent leading to the $\mathrm{Fe}^{\mathrm{III}}$ species rather than yielding the $\mathrm{Fe}^{\mathrm{IV}}$-oxo directly. Our findings are consistent with those reported by Hirao et al. for the reaction of $\left[\mathrm{Fe}^{\prime \prime}(\mathrm{TMC})\right]^{2+}$ with $\mathrm{H}_{2} \mathrm{O}_{2}$ in the absence of base. ${ }^{[21]}$

In summary, we demonstrate that the introduction of a pendant amine group in the second coordination sphere of a non

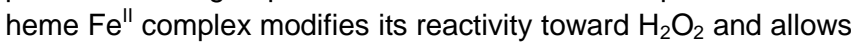
the direct formation of an $\mathrm{Fe}^{\mathrm{IV}}$-oxo intermediate instead of the

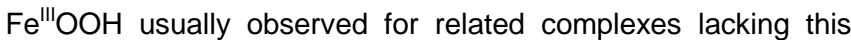
second sphere moiety. To our knowledge, this is the first time that such an effect is demonstrated in an intra-molecular fashion. Activation parameters measured during the process correlate with the values previously associated to heterolytic $\mathrm{O}-\mathrm{O}$ bond cleavage in the literature. The large $\left(\mathrm{k}_{H} / \mathrm{k}_{\mathrm{D}}\right) \mathrm{KIE}$ is also in good agreement with the involvement of the amine group as an acid/base relay. Our mechanism is supported by density functional theory calculations, which shows that the mechanism involves a proton transfer from the proximal $\mathrm{OH}$ group of $\mathrm{H}_{2} \mathrm{O}_{2}$ towards the distal one, via the transient protonation of the pendant amine group. More precisely, the initial proton transfer to the alkylamine is followed by a homolytic O-O bond cleavage accompanied by proton-coupled electron transfer to form the $\mathrm{Fe}^{\mathrm{IV}}$-oxo species.

\section{Acknowledgements}

The authors thank the Labex CHARMMMAT as well as the Agence Nationale de la Recherche (ANR BIOXICAT; 12-JS070007-01) for financial support. M.Q.E.M. thanks the Ministry of Higher Education Malaysia for a studentship. J.-M. L. thanks the Labex ARCANE and CBH-EUR-GS (ANR-17-EURE-003) for partial funding. This work was also supported by the ECOSTBio Action CM1305.

Keywords: Fe complex $\cdot \mathrm{O}-\mathrm{O}$ bond breaking $\cdot \mathrm{Fe}^{\mathrm{IV}}$-oxo $\cdot$ mechanism $\bullet N$ ligand
H. J. H. Fenton, J. Chem. Soc., Trans. 1894, 65, 899-910. F. Haber, J. Weiss, Proc. R. Soc. London Ser. A 1934, 147, 332351.

C. Walling, Acc. Chem. Res. 1975, 8, 125-131.

C. Walling, Acc. Chem. Res. 1998, 31, 155-157.

W. C. Bray, M. H. Gorin, J. Am. Chem. Soc. 1932, 54, 2124-

2125.

G. Olivo, O. Cussó, M. Borrell, M. Costas, J Biol Inorg Chem

2017, 22, 425-452.

S. Goldstein, D. Meyerstein, Acc. Chem. Res. 1999, 32, 547-

550 .

6.

S. Kal, L. Que, J Biol Inorg Chem 2017, 250, 625-27.

P. F. Fitzpatrick, Biochemistry 2003, 42, 14083-14091.

S. C. Peck, W. A. van der Donk, J Biol Inorg Chem 2017, 22, 381-394.

A. R. McDonald, L. Que Jr., Coord. Chem. Rev. 2013, 257, 414428.

W. Nam, Acc. Chem. Res. 2007, 40, 522-531.

J. J. Girerd, F. Banse, A. J. Simaan, Struct. Bond. 2000, 97, 145177.

S. V. Kryatov, E. V. Rybak-Akimova, S. Schindler, Chem. Rev. 2005, 105, 2175-2226.

S. K. Padamati, A. Draksharapu, D. Unjaroen, W. R. Browne, Inorg. Chem. 2016, 55, 4211-4222.

N. Ségaud, J.-N. Rebilly, K. Sénéchal-David, R. Guillot, L. Billon, J.-P. Baltaze, J. Farjon, O. Reinaud, F. Banse, Inorg. Chem.
H. Bataineh, O. Pestovsky, A. Bakac, Chem. Sci. 2012, 3, 1594-
2013, 52, 691-700.

F. Li, J. England, L. Que Jr., J. Am. Chem. Soc. 2010, 132 2134-2135.

J. Bautz, M. R. Bukowski, M. Kerscher, A. Stubna, P. Comba, A. Lienke, E. Münck, L. Que, Angew. Chem. Int. Ed. 2006, 45, 5681-5684.

S. Bang, S. Park, Y.-M. Lee, S. Hong, K.-B. Cho, W. Nam, Angew. Chem. Int. Ed. 2014, 53, 7843-7847. H. Hirao, F. Li, L. Que Jr., K. Morokuma, Inorg. Chem. 2011, 50, 6637-6648.

E. Derat, S. Shaik, J Phys Chem B 2006, 110, 10526-10533.

A. Hazell, C. J. McKenzie, L. P. Nielsen, S. Schindler, M. Weitzer, J. Chem. Soc., Dalton Trans. 2002, 310-317.

P. Mialane, A. Nivorojkine, G. Pratviel, L. Azéma, M. Slany, F.

Godde, A. Simaan, F. Banse, T. Kargar-Grisel, G. Bouchoux, et al., Inorg. Chem. 1999, 38, 1085-1092.

C. Buron, K. Sénéchal-David, R. Ricoux, J.-P. Le Caër, V.

Guérineau, P. Méjanelle, R. Guillot, C. Herrero, J.-P. Mahy, F.

Banse, Chem. Eur. J. 2015, 21, 12188-12193.

J. Kaizer, E. J. Klinker, N. Y. Oh, J.-U. Rohde, W. J. Song, A.

Stubna, J. Kim, E. Münck, W. Nam, L. Que, J. Am. Chem. Soc. 2004, 126, 472-473.

Transfer of this highly unstable species into the Mössbauer cuvette may have caused some degradation, leading to the observed $90 \%$ purity for the sample. If the conversion in $1^{1 \mathrm{~V}} \mathrm{O}$ was $90 \%$, the value of the extinction coefficient for the $740 \mathrm{~nm}$ chromophore would be similar, $210 \mathrm{M}^{-1} \cdot \mathrm{cm}^{-1}$.

O. Horner, C. Jeandey, J.-L. Oddou, P. Bonville, C. J. McKenzie, J.-M. Latour, Eur. J. Inorg. Chem. 2002, 2002, 3278-3283.

M. Martinho, P. Dorlet, E. Rivière, A. Thibon, C. Ribal, F. Banse, J.-J. Girerd, Chem. Eur. J. 2008, 14, 3182-3188.

V. Balland, F. Banse, E. Anxolabéhère-Mallart, M. Nierlich, J.-J.

Girerd, Eur. J. Inorg. Chem. 2003, 2003, 2529-2535.

M. R. Bukowski, P. Comba, C. Limberg, M. Merz, L. Que, T.

Wistuba, Angew. Chem. Int. Ed. 2004, 43, 1283-1287.

G. Roelfes, V. Vrajmasu, K. Chen, R. Y. N. Ho, J.-U. Rohde, C.

Zondervan, R. M. la Crois, E. P. Schudde, M. Lutz, A. L. Spek, et al., Inorg. Chem. 2003, 42, 2639-2653.

J. Everse, K. E. Everse, M. B. Grisham, Peroxidases in Chemistry and Biology, Crc, Boca Raton, 1991.

H. B. Dunford, Heme Peroxidases, Wiley-VCH, New York, 1999.

F. G. Cantú Reinhard, A. S. Faponle, S. P. de Visser, J. Phys. Chem. A 2016, 120, 9805-9814.

T. Yang, M. G. Quesne, H. M. Neu, F. G. Cantú Reinhard, D. P. Goldberg, S. P. de Visser, J. Am. Chem. Soc. 2016, 138, 1237512386.

F. G. Cantú Reinhard, M. A. Sainna, P. Upadhyay, G. A. Balan, D. Kumar, S. Fornarini, M. E. Crestoni, S. P. de Visser, Chem. Eur. J. 2016, 22, 18608-18619.

A. Timmins, M. Saint-André, S. P. de Visser, J. Am. Chem. Soc. 2017, 139, 9855-9866.

A. S. Faponle, M. G. Quesne, C. V. Sastri, F. Banse, S. P. de Visser, Chem. Eur. J. 2015, 21, 1221-1236. 
Entry for the Table of Contents (Please choose one layout)

Layout 1:

\section{COMMUNICATION}

A novel synthetic iron(II) complex bearing a second sphere intramolecular base efficiently forms an iron(IV)-oxido species in the presence of $\mathrm{H}_{2} \mathrm{O}_{2}$. Mechanistic studies demonstrate an overall heterolytic cleavage of the $\mathrm{O}-\mathrm{O}$ bond constituted of an homolytic cleavage with a concerted proton coupled electron transfer.

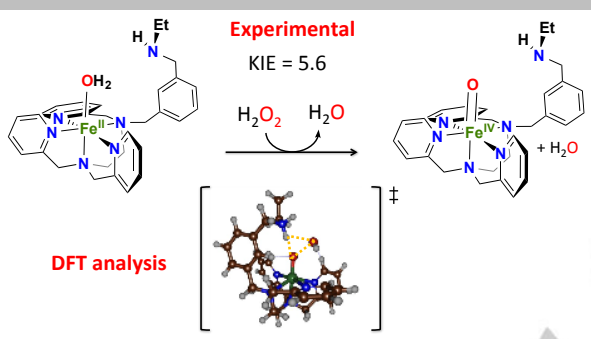

via homolytic O-O cleavage and PCET
Khaled Cheaib, Muhammad Qadri

Effendy Mubarak, Katell Sénéchal-

David, Christian Herrero, Régis

Guillot, Martin Clémancey, Jean-Marc

Latour, Sam P. de Visser, * Jean-

Pierre Mahy, Frédéric Banse, *

Frédéric Avenier*

Page No. - Page No.

Selective formation of an $\mathrm{Fe}^{\mathrm{IV}} \mathrm{O}$ or

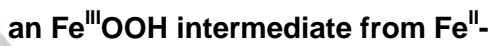
$\mathrm{H}_{2} \mathrm{O}_{2}$ : controlled heterolytic vs homolytic $\mathrm{O}-\mathrm{O}$ bond cleavage by 